\title{
EXAMINATION AND EVALUATION OF CLASS TEACHERS' OPINIONS REGARDING THEIR OWN PROFESSIONAL PERFORMANCE
}

\author{
Acar $\mathrm{M}^{1}{ }^{\square}(\mathrm{D})$, Demirdag A 2 (D), Oguz B ${ }^{3}$ (iD) \\ ${ }^{1}$ Principal of Pinarhisar Primary School, Kozluk, Batman, Turkey \\ ${ }^{2}$ Principal of Beyçayırı Secondary School, Beşiri, Batman, Turkey \\ 3 Karatay Primary School Class Teacher, Batman, Turkey
}

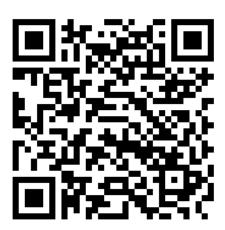

Received 17 September 2021

Accepted 17 October 2021

Published 31 October 2021

\section{CorrespondingAuthor}

Acar M, muratacar8692@gmail.com

DOI

10.29121/granthaalayah.v9.i10.2021 .4319

Funding: This research received no specific grant from any funding agency in the public, commercial, or not-for-profit sectors.

Copyright: (C) 2021 The Author(s). This is an open access article distributed under the terms of the Creative Commons Attribution License, which permits unrestricted use, distribution, and reproduction in any medium, provided the original author and source are credited.

\section{ABSTRACT}

The objective of this work is to take the opinion of form teachers related to their own performance's evaluation process.

The research has been done qualitative data model which is one of the descriptive scanning models. The data of the study was collected by a scale developed by the researcher. The sample of the study has been consisted of 40 form teachers working in of Batman city center 2019-2020 academic year. In the analysis of the data, class population was too crowded, the decrease in the value of the teachers in the community and the lack of communication with the parents, the difficulties experienced in the provision of educational materials and the teachers of the dual education application had negative effects on their performance.

Keywords: Performance, Classroom Teacher, The Performance of Teacher

\section{INTRODUCTION}

Teaching profession in the National Education Basic Law No. 1739; “Teaching is a specialized profession that takes on the education, training and related management duties of the State. Teachers are responsible for performing these duties in accordance with the aims and basic principles of Turkish National Education. Preparation for the teaching profession is provided by general culture, special field education and pedagogical formation. In order for them to gain the qualifications mentioned above, it is essential to ensure that pre-service teachers receive higher education regardless of their education level. This education is organized in a way that allows horizontal and vertical transitions at pre-bachelor, undergraduate and graduate levels. teaching profession; After the candidacy period, it is divided into three career steps as teacher, specialist teacher and head teacher." (METK Article: 43). With the said law, the framework, status, eligibility conditions and career steps of the teaching profession are specified.

Also; In the Regulation on Preschool and Primary Education Institutions of the Ministry of National Education, the duties and responsibilities of the teacher are stated as follows. 
1) Pre-school and primary school teachers are required to plan and implement education and training activities in the group/class/branch assigned to them according to the principles specified in the education and training program, to participate effectively in school education andtraining outside the classroom, and to responsible for carrying out their duties.

2) In primary schools, classroom teachers teach the class they teach in the next class. However, if their request is approved by the administration, they can have another class taught.

3) It is essential that all classes are taught by classroom teachers in primary schools. However, Foreign Language, Religious Culture and Moral Knowledge courses are taught by the permanent field teachers of the school. In case there is no permanent field teacher in the school; these courses are taught in the same education region, or by permanent field teachers in other education regions. In case the need is not met by the permanent field teachers, those who meet the conditions of being appointed as a teacher in the field that is the basis for the assignment as of the higher education program, they graduated may be assigned to teach these courses in return for additional courses. In this way, if the need cannot be met, these courses can be taught by classroom teachers who have completed their higher education in the aforementioned fields or by teachers who have received an in-service training certificate in this field, through course exchange. In cases where this is not possible, these lessons are taught by the class teacher.

4) When Foreign Language, Religious Culture and Moral Knowledge courses are taught by field teachers in primary schools, classroom teachers perform the education and training duties given by the administration during these course hours.

5) Teachers are considered to be on leave during summer and rest holidays. Apart from sick and other excuses, no annual leave is given.

6) Teachers cannot be assigned any duties other than education, training and management duties.

7) Teachers are obliged to attend all kinds of official meetings held at school, local liberation days and national holidays in examination commissions where they are assigned as commission members and watchdogs. Teachers are notified in writing at least five days in advance of the assignment and the time of the meetings. The agenda of the meeting is prepared by taking the opinions of the teachers. Meetings are held on working days so as not to interrupt classes.

8) In schools where the number of assistant principals and teachers is not sufficient, the deputy principal and teachers are assigned more than one duty per week.

9) In primary education institutions; According to the shift schedule drawn up by the school directorate, taking into account the school's buildings and facilities and the number of students, boarding, daytime, normal or dual education, the teachers keep watch during the day in schools that provide normal education, and in their own circuit in schools that offer dual education. In addition, the duty on duty during the lunch break in schools where normal education is given is arranged by the school administration in a rotational and balanced manner, taking into account the rest periods of the teachers on duty.

10) If the teacher teaches courses in more than one school, he or she keeps watch at the school where he receives his salary, or at the school where he teaches the most, if there is no course at the school where he receives the salary. 
11) If the number of teachers in the school is sufficient, teachers who have completed 20 years of service for women and 25 years for men are not assigned a duty on duty unless they request it. However, in case of need, these teachers are also assigned a duty of watch.

12) Pregnant teachers are not assigned a duty of duty until the end of the one-year period following the end of the postpartum maternity leave period, starting from the twenty-fourth week of pregnancy.

13) The watch duty starts 30 minutes before the start of the first lesson and ends 30 minutes after the end of the last lesson. However, this period may be shortened by the decision of the teachers' board, depending on the characteristics of the school, provided that it is not less than 15 minutes.

14) Teachers who do not come to duty without excuse

15) The principles to be followed during the shifts are discussed in the teachers' board, and the duty instruction for the duty teacher is prepared by the school administration. This instruction is announced to the teachers in writing.

16) From teachers; Persons with disabilities, those with a child with a disability, and those who have a disabled person to take care of are not given a duty of care. However, teachers in this situation are assigned a duty on duty, giving priority to their day preferences, if they so desire.

17) Special education teachers working in special education classrooms carry out their duty by continuing to supervise the students registered in their classes during break and meal times.

18) The order of the classroom, where there is no teacher for various reasons, is provided by the teacher on duty, who does not have a lesson at that time." (OÖİKY, MEB)

As can be seen, various responsibilities have been imposed on the teacher apart from the legal legislation and the education and training duties. Therefore, it is obvious that especially the classroom teacher should overcome these responsibilities and make great efforts to raise the adults of the future, whose personality will be shaped, in the light of the achievements aimed with education. In this profession, where there are so many expectations and responsibilities, which variables affect teacher performances in a positive or negative way. The performances of educators who train individuals who are the basis of society have been deemed worthy of examination in many studies.

Likewise, the personality traits of teachers and their competencies are very important in educating students. A lot of research has been done in this direction.

Teachers' proficiency level is not only important for children's level of knowledge and education process. Especially in the first years of children's education, teacher competencies are very effective in the development of their personalities.

It is seen that most of the teacher training institutions are insufficient in terms of many variables. Since the in-service training and other practices given to the teacher candidates who graduated from higher education institutions who are inadequate in terms of teaching staff, technological infrastructure and physical equipment are insufficiently carried out, it is possible to gain teacher competencies with the experience they have gained in the field of education.

Achieving the above-mentioned teacher competencies is possible through teacher training institutions or in-service training programs organized by the Ministry of National Education during the candidate teaching process. However, since this does not seem very possible with our current system, the individual who 
has been appointed to the teaching profession develops this experience by learning while actually performing their duties.

As in the world, our country is in a constant state of change depending on the changing world conditions. In parallel with this change in the Turkish education system, the constantly changing education programs are also constantly changing. In 2004, primary education programs were changed, and the 2004 curriculum was prepared. It is observed that the programs based on the constructivist philosophy have a structure that puts the student more in the center and proposes methods different from the traditional methods. Primary education programs have brought important changes in measurement and evaluation, as in many other structures. The new measurement and evaluation methods in primary education programs, unlike traditional measurement and evaluation methods, are process-oriented, follow the development of the student and consider evaluation as a part of learning Acat and Uzunkol (2010). Therefore, it requires the efforts of teachers to change and develop themselves against this dizzying speed of change and transformation. Another issue that cannot be ignored is the administrative skills of classroom teachers. Because there are facts that need to take an active role in problem solutions such as classroom management, healthy communication with parents, family-teacherschool management cooperation organization, participation in the administrative decision process aimed at solving the problems arising from internal and external dynamites of the school, being open to criticism.

Therefore, the classroom teacher should have a good assessor, adequate evaluator and managerial skills in addition to his/her teaching duties.

In this study, teachers' evaluation of their performance in classroom teaching and whether their performances are affected positively or negatively due to legislation and environmental factors are included. Based on the question asked, determinations were made in terms of performance evaluation.

\section{FINDINGS}

In this study, which was based on qualitative research, document analysis was carried out. Document analysis includes the analysis of written materials containing information about the facts and facts that are aimed to be investigated. Yildirim and Simsek (2011). Data were obtained with open-ended questions using the interview technique, one of the qualitative research methods.

Qualitative research is a type of research that includes the process of collecting data based on interviews, document scanning and observations, examining events in a natural environment, and revealing the reality of perception.

We can express the interview technique as taking the behavior of the person and his views on any subject with open-ended questions. The researcher records the answer given and the thought expressed by asking questions to the target audience whose thoughts he wants to receive. According to Stewart and Cash (1985), interviewing is "a mutual and interactive communication process based on the style of asking and answering questions, conducted for a predetermined and serious purpose". In this definition, the process is defined as "continuity and dynamism in communication;" reciprocal, "interaction between two or more individuals"; interactive, "the interpersonal bond formed between the individuals

involved in the interview"; A predetermined and serious purpose means that "at least one of the individuals involved in the interview has a specific purpose and is an effort to gather information for this purpose" (Cited by Yıldırım \& Şimşek, 2004). 
The universe of the study consists of classroom teachers working in primary schools, while the sample consists of 40 volunteer teachers working in the city center of Batman. The demographic characteristics of the participants participating in the study are given in Table 1 below.

\begin{tabular}{|c|c|c|c|c|c|c|}
\hline Code & Gender & $\begin{array}{c}\text { Graduation } \\
\text { Area }\end{array}$ & $\begin{array}{c}\text { Graduation } \\
\text { Status }\end{array}$ & Age & $\begin{array}{c}\text { Professional } \\
\text { Seniority }\end{array}$ & $\begin{array}{c}\text { Most Worked } \\
\text { Place (Urban - } \\
\text { Rural) }\end{array}$ \\
\hline S1 & M & $\begin{array}{c}\text { Classroom } \\
\text { Teachıng }\end{array}$ & LICENCE & 34 & 10 & Kent \\
\hline S2 & G & $\begin{array}{c}\text { Classroom } \\
\text { Teachıng }\end{array}$ & LICENCE & 41 & 15 & Kent \\
\hline S3 & M & $\begin{array}{c}\text { Classroom } \\
\text { Teachıng }\end{array}$ & LICENCE & 35 & 14 & Kent \\
\hline S4 & M & $\begin{array}{c}\text { Classroom } \\
\text { Teachıng }\end{array}$ & LICENCE & 48 & 24 & Kent \\
\hline S5 & M & $\begin{array}{c}\text { Classroom } \\
\text { Teachıng }\end{array}$ & LICENCE & 40 & 18 & Kent \\
\hline S6 & M & $\begin{array}{c}\text { Classroom } \\
\text { Teachıng }\end{array}$ & LICENCE & 46 & 16 & Kırsal \\
\hline S7 & M & $\begin{array}{c}\text { Classroom } \\
\text { Teachıng }\end{array}$ & LICENCE & 38 & 15 & Kent \\
\hline S8 & M & Biology & LICENCE & 42 & 18 & Kirsal \\
\hline S9 & M & $\begin{array}{c}\text { Classroom } \\
\text { Teachıng }\end{array}$ & LICENCE & 43 & 21 & Kent \\
\hline S10 & M & Agriculture & LICENCE & 49 & 23 & Kırsal \\
\hline S11 & M & Communication & LICENCE & 48 & 24 & Kent \\
\hline S12 & M & $\begin{array}{c}\text { Classroom } \\
\text { Teaching }\end{array}$ & LICENCE & 46 & 21 & Kent \\
\hline S13 & M & German & LICENCE & 52 & 27 & Kent \\
\hline S14 & $\mathrm{G}$ & $\begin{array}{c}\text { Classroom } \\
\text { Teachıng }\end{array}$ & LICENCE & 35 & 13 & Kent \\
\hline S15 & M & Biology & LICENCE & 42 & 20 & Kent \\
\hline S16 & G & $\begin{array}{c}\text { Classroom } \\
\text { Teachıng }\end{array}$ & LICENCE & 31 & 10 & Kent \\
\hline S18 & M & $\begin{array}{c}\text { Classroom } \\
\text { Teaching }\end{array}$ & LICENCE & 29 & 10 & Kent \\
\hline S17 & $\mathrm{G}$ & $\begin{array}{c}\text { Classroom } \\
\text { Teachıng }\end{array}$ & LICENCE & 38 & 12 & Kent \\
\hline S19 & M & $\begin{array}{c}\text { Classroom } \\
\text { Teachıng }\end{array}$ & LICENCE & 43 & 20 & Kent \\
\hline S20 & G & $\begin{array}{c}\text { Classroom } \\
\text { Teachıng }\end{array}$ & LICENCE & 42 & 19 & Kırsal \\
\hline S21 & G & $\begin{array}{c}\text { Classroom } \\
\text { Teachıng }\end{array}$ & LICENCE & 42 & 12 & Kent \\
\hline S22 & G & $\begin{array}{c}\text { Classroom } \\
\text { Teachıng }\end{array}$ & LICENCE & 38 & 16 & Kent \\
\hline S23 & $\mathrm{M}$ & $\begin{array}{c}\text { Classroom } \\
\text { Teaching }\end{array}$ & LICENCE & 37 & 14 & Kent \\
\hline S24 & M & $\begin{array}{c}\text { Classroom } \\
\text { Teachıng }\end{array}$ & LICENCE & 43 & 20 & Kent \\
\hline $\mathrm{S} 25$ & M & $\begin{array}{c}\text { Classroom } \\
\text { Teaching }\end{array}$ & LICENCE & 48 & 26 & Kent \\
\hline
\end{tabular}




\begin{tabular}{|c|c|c|c|c|c|c|}
\hline S26 & M & $\begin{array}{c}\text { Classroom } \\
\text { Teachıng }\end{array}$ & LICENCE & 42 & 19 & Kirsal \\
\hline S27 & $\mathrm{G}$ & $\begin{array}{c}\text { Classroom } \\
\text { Teachıng }\end{array}$ & LICENCE & 41 & 20 & Kent \\
\hline S28 & $\mathrm{G}$ & $\begin{array}{c}\text { Classroom } \\
\text { Teachıng }\end{array}$ & LICENCE & 48 & 27 & Kent \\
\hline S29 & G & $\begin{array}{c}\text { Classroom } \\
\text { Teachıng }\end{array}$ & LICENCE & 34 & 12 & Kent \\
\hline S30 & $\mathrm{G}$ & Agriculture & LICENCE & 47 & 23 & Kent \\
\hline S31 & G & $\begin{array}{c}\text { Classroom } \\
\text { Teachıng }\end{array}$ & LICENCE & 35 & 10 & Kent \\
\hline S32 & G & $\begin{array}{c}\text { Classroom } \\
\text { Teachıng }\end{array}$ & LICENCE & 38 & 14 & Kent \\
\hline S33 & $\mathrm{G}$ & $\begin{array}{c}\text { Classroom } \\
\text { Teaching }\end{array}$ & LICENCE & 64 & 35 & Kent \\
\hline S34 & G & $\begin{array}{c}\text { Classroom } \\
\text { Teachıng }\end{array}$ & LICENCE & 34 & 11 & Kent \\
\hline S35 & $\mathrm{G}$ & $\begin{array}{c}\text { Classroom } \\
\text { Teachıng }\end{array}$ & LICENCE & 40 & 10 & Kent \\
\hline S36 & G & $\begin{array}{c}\text { Classroom } \\
\text { Teachıng }\end{array}$ & LICENCE & 34 & 11 & Kent \\
\hline S37 & G & $\begin{array}{c}\text { Classroom } \\
\text { Teachıng }\end{array}$ & LICENCE & 35 & 14 & Kent \\
\hline S38 & $\mathrm{G}$ & $\begin{array}{c}\text { Classroom } \\
\text { Teachıng }\end{array}$ & LICENCE & 44 & 20 & Kent \\
\hline S39 & $\mathrm{G}$ & $\begin{array}{c}\text { Classroom } \\
\text { Teachıng }\end{array}$ & LICENCE & 37 & 14 & Kirsal \\
\hline S40 & M & $\begin{array}{c}\text { Classroom } \\
\text { Teachıng }\end{array}$ & LICENCE & 43 & 18 & Kırsal \\
\hline
\end{tabular}

One of the most common and important goals of both educational science and management science is to enable people to make the most of their talents. Perceptions of self-efficacy can contribute to explaining the positive and negative reasons for the difference between what individuals believe and what they can achieve. In this conceptual study based on qualitative observation, self-efficacy, study time and performance changes were explained in terms of teachers.

The data of the research were collected from a total of 40 volunteer teachers working in ten different schools in the city center of Batman in the 2019-2020 academic year. At the beginning of the application, the purpose of the research was explained to the participants and the importance of writing their true feelings and thoughts was explained. The application took 10-15 minutes.

A single-question measurement tool was applied to the classroom teachers working in ten different schools in the city center of Batman.

"What do you think about your teaching performance?" question was posed.

Accordingly, the opinions of the participants were coded as "S" in terms of expressing the "class teacher" for the participants after the demographic information, without writing their names, and each participant was given a number as "S1, S2, S3, S4, S39, S40" next to the code.

The answers given by the participants to the question asked were written in the order of coding, the answers were examined and an evaluation was made. 
Descriptive analysis and content analysis techniques were used to analyze the research data. descriptive analysis; It is an analysis technique in which the data obtained are summarized and interpreted according to previously determined themes, direct quotations are frequently used to reflect the views of the interviewees in a striking way, and the results are interpreted within the framework of cause-effect relationships Yıldırım and Şimşek (2003). According to Yildirim and Simsek (2011), the main purpose of content analysis is to reach concepts and relationships that can explain the collected data. The basic process in content analysis is to gather similar data within the framework of certain concepts and themes and to organize and interpret them in a way that the reader can understand.

The data obtained from the forms were first transferred to the Office program, read a few times, notes were taken, themes (categories) were revealed by grouping those who expressed similar thoughts, and descriptive and content analyzes were made.

Validity in qualitative research means that the researcher observes the researched phenomenon as it is and as impartially as possible (Yıldırım \& Şimşek, 2005). It can be defined as revealing a social event with all its reality. Another investigative validity; expressed as the proximity of what we believe to measure and what we plan to measure (Roberts \& Priest, 2006. cited in Yıldırım).

To ensure the reliability of the research; The way the data was collected, how it was interpreted and what was done to reach the results were explained in detail, and the results were associated with the data. The researcher made maximum effort not to reflect his individual assumptions, judgments, orientations, and differences and alternative views were considered important. The raw data collected were filed for use by other researchers if needed.

In this study, the data collection tool was distributed and the participants were interviewed face to face. The data collection tools that the participants answered according to their own views were meticulously classified, and the researcher made the analysis without adding his feelings and prejudices.

\section{RESULTS}

Table 2 Categories of teachers' performance as a result of the analysis of the data.

\begin{tabular}{cccc}
\hline SN & Theme & (f) & (\%) \\
\hline $\mathbf{1}$ & I find myself successful. & 28 & 70 \\
\hline $\mathbf{2}$ & Parent's indifference affects my performance negatively. & 12 & 30 \\
$\mathbf{3}$ & Crowded classrooms negatively affect my performance. & 10 & 25 \\
\hline $\mathbf{4}$ & Over the years, I believe my performance has decreased.. & 7 & 18 \\
$\mathbf{5}$ & Over the years, I believe that my performance has increased with professional & 7 & 18 \\
\hline $\mathbf{6}$ & The performance of school administration is effective on teacher performance. & 4 & 10 \\
\hline $\mathbf{7}$ & The constant changing of the curriculum negatively affects my performance. & 3 & 8 \\
\hline $\mathbf{8}$ & Not giving the necessary value to the teacher negatively affects my performance. & 2 & 5 \\
$\mathbf{9}$ & Low wages negatively affect my performance.. & 2 & 5
\end{tabular}

When the data collected from a total of 40 volunteer teachers working in ten different schools in the city center of Batman are analyzed in the 2019-2020 academic year, it is seen that the majority are satisfied with their performance. (S3, S4, S6, S7, S8, S9, S11, S12, S14, S15, S18, S19, S20, S23, S24, S25, S26, S28, S30, S31, S32, S33, S34, S35, S36, S37, S38, S39). It was concluded that $28(70 \%)$ of the classroom teachers participating in the research were satisfied with their own 
performance. The opinions of some of the teachers who expressed satisfaction with their performance are given below.

"I have good class dominance. I have a good command of curriculum issues; I determine the individual needs of the student and apply methods accordingly. I have good social relations, communicate with parents and can persuade them. I can use technological tools in my classroom when necessary. In my classroom, I support the lessons with activities. I build student, parent, teacher relationships on respect and love. (P20)"

"I have a personality that is open to innovations, self-respecting and self-aware, reliable, solid and consistent in behavior. I am someone who loves children and is happy to be with them. I am a knowledgeable, resourceful and active teacher in my field. I am well prepared to answer all kinds of different questions. (P21)"

"I am currently satisfied with my teaching performance. Frankly, we can describe the first years of my teaching as an apprenticeship. Although I am tired more physically by working harder, I definitely do not think that I am as productive as I am now. Over the years, I have realized that many of the methods we used in our first years of employment were wrong. Over the years, I think that I have been performing my profession much more professionally and efficiently...(P30)"

"I love the school, my class and the students. We have a nice environment of friends; I think that I am efficient and I am sufficient for the students. I am a person who is open to innovations, because of the curriculum, parents are unconsciously involved in the teacher without empathizing, they always train their children with self-centered thinking from a friend environment, when I see such behaviors, my performance decreases when I encounter such parents. I see the teaching profession as a valuable and respected profession. (P32)"

"I am able to establish positive relationships with children, and I prepare learning environments that are suitable for children's skills and needs and that will enable each child to experience a sense of success. I can use technology effectively in the classroom. I believe in the power of school-family cooperation, so I attach importance to working with the family. I take care to work in harmony with my teammates. I try to enrich my professional knowledge and experience by closely following the developments in my field. (P36)"

In the research, parent behavior is the most important reason that negatively affects performance. (S2, S4, S5, S10, S13, S15, S18, S24, S27, S29, S30, S32). 12 of the classroom teachers (30\%) stated that the negative behaviors of the parents affected their performance negatively. The views of some of those who expressed this dissatisfaction are given below.

"I think my performance has decreased due to economic reasons and parental indifference. (S5)"

"Despite the negativities arising from class sizes and parent performance, and some of my shortcomings, I think that I have done my duty to a good degree. (P13)"

"... After working for a few years, I believe that my teaching performance has increased with both my self-confidence and the experience I have gained. However, constant curriculum changes, dealing with small age group education and unrelated parent situations can cause mental fatigue and even a certain level of boredom (S18)".

"I cannot fully demonstrate my performance in this school due to the lack of conditions and opportunities. For example, I want to do an in-class activity or project. I'm stuck on the parent block. ...... (P27)" 
"I love the school, my class, the students. We have a nice environment of friends; I think that I am efficient and I am sufficient for the students. I am a person who is open to innovations, because of the changing curriculum, parents are unconsciously involved in the teacher without empathizing, they always train their children with self-centered thinking from a friend environment, when I see such behaviors, my performance decreases when I encounter such parents. I see the teaching profession as a valuable and respected profession (P32)"

The positive/negative effects of parent indifference on teacher behaviors and educational activities in general have been determined by many scientific studies. If the success of educational activities is based on a solid foundation of school-parent cooperation, significant progress will be achieved. Schools are expected to be effective in the environment they control and address. Because the school should not limit its mission only to the education it gives to its students, but should also take on the responsibility of education of the family in the education area. The education that the parents do not attend is missing one leg and it cannot be expected to be successful. Because the way for schools to make students gain the desired behavior is through the family, otherwise it is not possible for the family to be successful in changing the behaviors on personality development, even though successful studies have been made in teaching without the support of the society. The family should be aware of the activities of the school, the socio-economic and cultural level of the family, and should add the support of the family to the education process by keeping the channels open for effective communication.

Another important factor affecting the teacher's performance negatively is that the classes are crowded (S2, S4, S8, S10, S13, S15, S16, S22, S23, S27). 10 (25\%) of the classroom teachers who participated in the research expressed this negativity and stated that it affected their performance. The opinions of some of the teachers who expressed this view are given below.

"About my performance; I consider myself successful. Class sizes are at the top of the factors that affect our performance. The existing ones definitely affect negatively (Q8)."

"As for the reason why, I can't see myself enough; Class sizes are crowded, schools are not supported economically, the number of sensitive parents is low, environmental conditions and school buildings are not suitable for education (S10).

"I work as a classroom teacher. I think that the main factors affecting my performance are the crowded class size (45 students) and the socio-cultural and academic inadequacy of the parents, which are not caused by me. Despite this, I'm trying to improve my performance and I think I'm doing pretty well. (P15)"

"I think that I could not fully demonstrate my performance due to not being able to allocate one-to-one time to students due to the large number of classrooms... (P22)"

Another striking theme in the study is that there are teachers who believe that their performance has decreased over the years due to various reasons. (S1, S2, S5, S10, S14, S15, S17). Seven of the classroom teachers (18\%) stated that their performance had decreased over the years. The opinions of some of those who expressed this situation are given below.

"I am not satisfied with my teaching performance. The reason for this is due to my unrelated parents and my students who, no matter how hard I try, can't see the result I want. When I first started this profession, I felt my performance at the highest level. I showed great dedication to my profession both during school hours and outside of school hours. I was making an effort to bring something to the children, not only as a lesson but also socially. But when I saw that the necessary 
value was not given to the teacher, I started to feel alienated from the profession. For this reason, even I don't like my performance right now. The crowded classrooms, pampered students, and disinterested parents made me feel like I couldn't succeed no matter how hard I tried. I hope that the conditions will improve and I will do this job with my old excitement (S2)"

"When I first started, I was a very idealistic teacher. I still think that I am, but I think that I have become atrophied compared to the old years due to working in primary school for a long time. Because I teach simple lessons for primary school students and this prevents me from improving myself. I am aware that I have good communication with students, but sometimes I have a hard time getting down to their level. I think that teaching is a job of experience and with each passing year I gain more and more experience in how I should treat students. (P14)"

"In the first years of my career, I was a more idealistic teacher, giving importance to differences, and working by considering individual differences. I think I have become more monotonous in recent years... (P17)"

A situation opposite to the previous category is teachers who believe that their performance increases as their professional experience increases... (S3, S9, S11, S18, $\mathrm{S} 28, \mathrm{~S} 30, \mathrm{~S} 31)$. Seven of the classroom teachers (18\%) stated that their performance had increased over the years. A few examples of this view are given below.

"I think my teaching performance is more productive than my early years. I can list the reasons as follows:

1) I am more experienced now. The effect of experience on teacher performance is indisputable.

2) In terms of educational material, I am now very advantageous compared to the past. This makes me more efficient.

3) There is a positive situation in the parents' approach to education. This motivates me even more.

4) The positive contribution of the school administration in the formation of the educational environment. I couldn't see this in some of the schools I worked at.

5) The learning level of the students is better now. Therefore, seeing the fruits of my labor increases my enthusiasm for work (S9)"

"In my first years as a teacher, I honestly floundered. Over the years, I realized how wrong I was in the teaching technique and classroom dominance. In fact, sometimes when I think of the students in my first years, I feel sorry for not being efficient enough. After working for a few years, I believe that my teaching performance has increased with both my self-confidence and the experience I have gained. However, constant curriculum changes, dealing with small age group education and unrelated parent situations can cause mental fatigue and even a certain level of boredom. (P18)"

"The problems and events I experienced in the first years of my profession came back to me as an experience. Now I see myself as more competent, controlled, nurturing, patient. Even though I am a teacher, I continue to learn from my students every year. Continuing to learn while teaching is one of the beauties of this profession. Although I cannot say that I have become a good teacher, I think that I am on this path. (P28)"

In the study, it was emphasized by some teachers that the attitudes of the school administration had positive or negative effects on the teacher's performance (S9, S11, S29, S40). 4 (10\%) of the classroom teachers who participated in the research expressed this situation and stated that the performance of the school 
administration was effective on the performance of the teacher. The views of some of the teachers who expressed this view are given below.

"I would like to evaluate my teaching performance in two separate periods. 1. Term During the periods I worked in rural areas, the lack of sufficient tools and equipment and the negative parent profile inevitably affected my performance negatively as I did not receive enough feedback. In the 2 nd semester, I reached the pinnacle of the pleasure of my teaching profession, because both the positive approach of the school administration and the approach to the supply of school equipment. In addition, the positive view of the student and parent profile and the positive view of education are the factors that keep our performance at a high level. (S11)"

"First of all, I think that a teacher's performance depends on the school he works at, the school administration, and the parent-student profile. I find my teaching performance sufficient in terms of establishing an effective classroom management, transferring the theoretical knowledge to the students in practice, and improving student behaviors... (S29)"

"... The general attitudes and behaviors required by the teaching profession, the ability to use environmental opportunities to support the learning process, and the school administrator can sometimes affect positively or negatively. As a result; In order for the teaching performance to be better than other developed countries, the performance of each teacher will be at the highest level if factors and conditions such as a good educational environment, good administration, readiness of the students, and good wages are provided (S40)"

In the study, teachers stated that the curriculum changes frequently as another issue that negatively affects performance (S18, S30, S32). Three of the classroom teachers $(8 \%)$ stated that the changing curriculum negatively affected their performance. The opinions of those who expressed this situation are given below.

"... After working for a few years, I believe that my teaching performance has increased with both my self-confidence and the experience I have gained. However, constant curriculum changes, dealing with small age group education and unrelated parent situations can cause mental fatigue and even boredom to a certain extent (S18).

"I am currently satisfied with my teaching performance. Frankly, we can describe the first years of my teaching as an apprenticeship. Although I am tired more physically by working harder, I definitely do not think that I am as productive as I am now. Over the years, I have realized that many of the methods we used in our first years of employment were wrong. Over the years, I think that I have been performing my profession much more professionally and efficiently. As for the negativity part, constant program change, parent behaviors, distractions caused by the lack of attention in students with technology cause physical and mental fatigue (S30).

"I love the school, my class, the students. We have a nice environment of friends, I think that I am efficient and I am sufficient for the students. I am a person who is open to innovations, because of the changing curriculum, parents are unconsciously involved in the teacher without empathizing, they always train their children with self-centered thinking from a friend environment, when I see such behaviors, my performance decreases when I encounter such parents. I see the teaching profession as a valuable and respected profession (P32)."

Another theme that emerged in the research is that teachers do not see the value they deserve and that being ignored negatively affects teacher performance 
(S2, S3). Two of the classroom teachers (5\%) stated that this situation negatively affected their performance. Those who expressed this view are listed below.

"I am not satisfied with my teaching performance. The reason for this is due to my unrelated parents and my students who, no matter how hard I try, can't see the result I want. When I first started this profession, I felt my performance at the highest level. I showed great dedication to my profession both during school hours and outside of school hours. I was making an effort to bring something to the children, not only as a lesson but also socially. But when I saw that the necessary value was not given to the teacher, I started to feel alienated from the profession. For this reason, even I don't like my performance right now. The crowded classrooms, pampered students, and disinterested parents made me feel like I couldn't succeed no matter how hard I tried. I hope that the conditions will improve and I will do this job with my old excitement (S2)."

"When the impression gained in teaching life, life experience and teaching experience are combined, a much more productive teaching emerges. The negative aspect is that the gradual decrease in respect for teachers and education in the first years of teaching can affect motivation negatively (S3)."

Another category mentioned in the research is that teachers' financial concerns are not addressed and they are not paid the wage they deserve (S27, S40). Two of the classroom teachers (5\%) stated that not getting the wages they deserve had a negative impact on their performance. The opinions of those who expressed this are given below.

"I cannot fully demonstrate my performance in this school due to the lack of conditions and opportunities. For example, I want to do an in-class activity or project. I'm stuck on the parent block. I organize classroom activities. The other circuit that I share the same class with wears out the students. Sometimes I get discouraged by my colleagues at school. Actually, that's not me. I'm capable of doing a lot of extra stuff. But I still do more than I should. My conscience is clear in terms of professional performance, but I am not happy. I only do this job because of my love for children. This gives me happiness. Even our salary is a ridiculous number. When someone who doesn't know about the subject asks, I hesitate to say that number. This is not the pay class teachers deserve.

We are the foundation of every profession. There is still a lot to write about, but we will suffice as much as there is a time limit (P27)."

"... As a result; Every teacher's performance will be at the highest level if factors and conditions such as a good educational environment, good administration, readiness of students, and good wages are provided so that teaching performance can be better than other developed countries (S40).

Emerging in the analysis of the data; It was stated that the majority of the teachers saw their performance as sufficient, the indifference of the parents, the crowded classes, the frequent changes in the curriculum, and the negative effects of the teacher's performance. In addition, the fact that the teacher does not receive the respect he deserves in the society and does not get paid enough to eliminate financial concerns has also been stated as a performance-reducing factor. Another remarkable detail is the presence of the same number of participants who stated that their performance increased with experience compared to the first years of their profession, and those who believed that their performance decreased due to various reasons as the years progressed. It was also expressed that the attitudes and capacities of the school administration affect the performance positively or negatively. Another detail is that there is no significant difference between the 
thoughts of primary school graduates and teachers who graduated from different fields and work as primary school teachers.

\section{DISCUSSION AND CONCLUSION}

Achieving teacher competencies is possible through teacher training institutions or in-service training programs organized by the Ministry of National Education during the candidate teaching process. However, since this qualification does not seem very possible with our current system, the individual who is thrown into the teaching profession develops this experience by learning while actually performing his duties. Therefore, some of the classroom teachers, whose views and opinions we received in the education community, stated that they did not believe that they were as productive as they are now, as they did not know exactly what to do in the first years of teaching and how to provide classroom management. Indifference of the parents, constant change in the curriculum, double education, crowded classrooms, and insufficient educational materials were counted as other reasons that negatively affect the performance of the teacher. Likewise, they stated that the attitudes and capacities of the school administration affect teacher performance positively or negatively. The physical conditions of the school and the educational environment are among the other prominent results that greatly affect teacher performance.

In order not to experience the losses that we will call "generation loss" in the period until the teacher who starts to work as a candidate teacher gains experience, teacher training institutions should provide teacher competency during the teacher training process, while the Ministry of National Education should provide in-service training. Not leaving the work to be done in order to increase the interest of parents only to the school stakeholders, considering it as an educational problem, producing effective solutions, developing more effective policies in order to give the teaching profession the respect it deserves, a suitable education environment for teachers' professional development, providing personal rights at a level that can realize these, dual education. Constructing sufficient school buildings for the transition to normal education by ending the school, preventing the school and parents from coming together on financial issues by allocating a budget to the schools, providing the indispensable materials of education are among the works that can be done to make the teacher and school performance effective and efficient.

\section{REFERENCES}

Acat, M.B. and Uzunkol E.D. (2010). Views of Classroom Teachers on the Evaluation Process in Primary Education Curriculum. Electronic Journal of Social Sciences. Winter-2010 C.9 P.31 (001-027)

Altunay, E. and Oral G. Yalçınkaya, M. (2014). A Qualitative Research on Mobbing Practices in Educational Institutions. Sakarya University Journal of Life Education 4/1 (April/April 2014) pp.62-80. Retrieved from https://doi.org/10.19126/suje.37750

Danielson, C. and McGreal, T. (2000). Teacher Evaluation to Improve Professional Practice.

Erdem, A.R. (2007). Views of Classroom Teachers on the Effect of Administrative Problems Encountered on Performance. Retrieved from Pamukkale University Faculty of Education. Retrieved from http://dergipark.gov.tr/uefad/issue/16684/173367 
Hatipoğlu, A. and Kavas, E. (2016). The Effect of Parent Approaches on Teacher Performance. Journal of Human and Social Sciences Research Vol: 5, Issue: 4, 2016 Page: 1012-103. Retrieved from https://doi.org/10.15869/itobiad.90789

National Education Fundamental Law No. 1739 (Republic of Turkey Official Gazette, 24 June 1973, No: 14574)

Regulation on Preschool and Primary Education Institutions of the Ministry of National Education (Republic of Turkey Official Gazette, 28 July 2014, No: 29072)

Stewart, C. J. \& Cash, W. B. (1985). Interviewing: Principles and Practices, W.C. Brown Publishers (Dubuque, Iowa), 4th Edition.

Yildirim, A. and Simsek, H. (2011). Qualitative research methods in the social sciences

Yıldırım, A. and Şimşek, H. (2003). Qualitative research methods in the social sciences. Retrieved from https://dergipark.org.tr/en/download/articlefile/63326

Yıldırım, N. (2011). A Qualitative Analysis on School Principals' motivations. AİBU, Journal of the Faculty of Education, 11(1), 2011, 71-85 